\title{
High oxygen-reduction activity of silk-derived activated carbon
}

Tomoya Iwazaki ${ }^{1,2}$, Ryoujin Obinata ${ }^{1}$, Wataru Sugimoto ${ }^{1} \&$ Yoshio Takasu ${ }^{1}$

1. Department of Fine Materials Engineering, Faculty of Textile Science and Technology, Shinshu University, 3-15-1 Tokida, Ueda, Nagano 386-8567, Japan

2. Shinano Kenshi Co., Ltd., Engineered Materials Division, 1078, Kamimaruko, Ueda, Nagano 386-0498, Japan

\begin{abstract}
Activated carbon prepared from silk fibroin, which is free of metal elements, showed a high catalytic activity for the oxygen-reduction reaction (ORR). The activated carbon had a very high onset potential of $E_{\text {onset }}=0.83 \mathrm{~V}$ (vs. RHE) in oxygen saturated $0.5 \mathrm{M} \mathrm{H}_{2} \mathrm{SO}_{4}$ at $60{ }^{\circ} \mathrm{C}$. The $\mathrm{ORR}$ on the activated carbon proceeded by a four-electron process in the high-electrode-potential region; this gradualy decreased to a 3.5-electron reaction below about $0.6 \mathrm{~V}$ (vs. RHE). Only about $1 \%$ of nitrogen atoms (mostly quaternary) remained in the activated carbon by heat treatment at up to $1200{ }^{\circ} \mathrm{C}$ are responsible for the high catalytic activity. The open circuit voltage of a polymer electrolyte fuel cell using the activated carbon as the cathode and a platinum/carbon black anode under pure oxygen and hydrogen gases, respectively, both at 1 atmosphere, was $0.96 \mathrm{~V}$ at $27^{\circ} \mathrm{C}$.
\end{abstract}

Keywords: Silk fibroin; Activated carbon; Electrocatalyst; Oxygen reduction reaction; Fuel cell 
* Corresponding author. Tel: 8126821 5451; Fax: 81268229048.

E-mail address: ytakasu@shinshu-u.ac.jp (Y. Takasu).

\section{Introduction}

As an approach for the development of less-expensive cathode catalysts of polymer electrolyte fuel cells (PEFCs), various methods have recently been tried for introducing nitrogen into carbon materials to enhance their catalytic activity toward the oxygen reduction reaction (ORR) [1-15], because it has been proposed that nitrogen atoms in the carbon network participate directly or indirectly in the reaction. Techniques for nitrogen doping of carbon materials can be divided into two categories [1]: doping directly during the synthesis of the porous carbon material, and post-treatment of pre-synthesized carbon materials with nitrogen-containing precursor, e.g. $\mathrm{NH}_{3}$. On the other hand, the silk fibroin contain 18 types of amino acid, such as glycine and alanine, all of which contain nitrogen atoms within their molecular structures [16]. In this communication, we focus our attention on the probable contribution of the intrinsic nitrogen atoms in silk-derived activated carbon to the ORR.

\section{Experimental Section}

A Bombyx mori silk fibroin (Shinano Kenshi Co. Ltd., Japan) was used as the starting material after removing the sericin from the silk fiber [17]. The silk fibroin was carbonized by heat-treatment at $500{ }^{\circ} \mathrm{C}$ in a stream of $\mathrm{N}_{2}$ gas for 6 hours. The carbonized silk fibroin was ball milled and then further heat-treated at $700,900,1200$, or $1500^{\circ} \mathrm{C}$ under flowing $\mathrm{N}_{2}$ gas for 3 hours: the products are referred to as CS700, CS900 and CS1200, respectively. Steam activation of the carbonized silk fibroins was performed at $850{ }^{\circ} \mathrm{C}$ for 7 hours. The resulting activated carbons are denoted CS700-AC, CS900-AC and CS1200-AC.

Rotating ring-disk electrode equipment (RRDE; Nikko Keisoku Co., Ltd.; RRDE-1) was used to evaluate the ORR activity and the selectivity of the powder specimens of CS-ACs. The cell has a carbon-fiber counter electrode, a hydrogen reference electrode, and a glassy-carbon working electrode $(0.283$ $\mathrm{cm}^{2}$ ). The working electrode was prepared by the thin-film electrode method. Cyclic voltammograms (CVs) were measured in both $\mathrm{N}_{2}$ - and $\mathrm{O}_{2}$-saturated 0.5 $\mathrm{M} \mathrm{H}_{2} \mathrm{SO}_{4}$ solutions at $60{ }^{\circ} \mathrm{C}$. During cathodic potential sweep at $2000 \mathrm{rpm}$, an additional cathodic current due to the ORR was observed for the $\mathrm{CV}$ measured in the $\mathrm{O}_{2}$-saturated solution compared with that measured in the $\mathrm{N}_{2}$-saturated solution. The onset electrode potential, $E_{\mathrm{ORR}}$, for the ORR is defined as the potential where the additional cathodic current attained to -1.0 $\mu \mathrm{A} / \mathrm{cm}^{2}$-(geometric), $E_{\text {ORR }}$. 


\section{Results and Discussion}

Linear-sweep voltammograms of CS-ACs calcined at various temperatures for the ORR in $0.5 \mathrm{M} \mathrm{H}_{2} \mathrm{SO}_{4}$ (Fig. 1), showed that these CS-ACs have a considerably higher activity than either an activated carbon made from a phenolic resin or carbon black (Vulcan XC-72R). The onset potentials for ORR $\left(E_{\mathrm{ORR}}\right)$ of the electrode potential for CS-ACs were high compared with those of other carbon materials; the values of $E_{\mathrm{ORR}}$ for CS700-AC, CS900-AC, CS1200-AC, phenol resin-derived activated carbon, and carbon black were, respectively, $0.75,0.83,0.83,0.61$, and $0.51 \mathrm{~V}$ (vs. RHE). These values did not appear to depend on the surface areas of the activated carbons. The specific surface area of these carbon materials are listed in Table 1.

Although the usual reaction that occurs on carbon electrodes is far less than the four-electron reaction $\left(\mathrm{O}_{2}+4 \mathrm{H}^{+}+4 \mathrm{e}^{-} \rightarrow \mathrm{H}_{2} \mathrm{O}\right)$, there have been reports that reactions involving more electrons may take place on nitrogen-containing carbon electrodes [2-6]. Analyses of the ORR by a method involving a rotating ring-disk electrode showed that the ORR on CS900-AC proceeds by a 3.5 -electron reaction to give about $25 \%$ of hydrogen peroxide (Fig. 1, right-hand).

Figure 2 shows the polarization curve for a polymer electrolyte fuel cell (PEFC) with a membrane electrode assembly (MEA) and constructed with a Pt $(50 \mathrm{wt} \%) / \mathrm{C}$ catalyst anode, a Nafion ${ }^{\circledR} 117$ membrane, and a cathode comprising CS1200-AC mixed with Nafion ${ }^{\circledR}$ ionomer. The cell performance was markedly dependent on the amount of CS1200-AC that was used. Note that the open circuit voltage of this cell was very high: $0.96 \mathrm{~V}$ at $27^{\circ} \mathrm{C}$.

$\mathrm{X}$-ray diffraction (XRD) analysis of the various carbon materials (Fig. 3) suggests that graphitization of the CS-ACs increased gradually with increasing heat-treatment temperature. The nitrogen atoms incorporated in CS-ACs were examined by X-ray photoelectron spectroscopy (XPS), because it has been suggested that various types of nitrogen atoms, including pyridine-like nitrogen $(398.6 \mathrm{eV})$, pyrrole-like nitrogen $(400.5 \mathrm{eV})$, quaternary nitrogen $(401.3 \mathrm{eV})$, and oxide nitrogen $(402-405 \mathrm{eV})$, are present in nitrogen-containing carbons [18-22]. As the heat-treatment temperature increased, the proportion of pyridine-like $\mathrm{N}$ species decreased, and almost disappeared in the case of CS1200-AC, whereas some quaternary nitrogen $(401.3 \mathrm{eV})$ species remained even after heat-treatment at $1200^{\circ} \mathrm{C}$.

The nitrogen-to-carbon (N/C) ratios of the CS-ACs, as determined by XPS and by elemental analysis, are presented in Table 1. Because of insufficient carbonization, the catalytic activity of CS700-AC was considerably lower than those of CS900-AC and CS1200-AC. This investigation showed that quaternary nitrogen atoms make a major contribution to the ORR, as shown in Fig. 4 where the CS1200-AC showed a high activity for the ORR, even though it contained 
neither pyridine-like nitrogen nor pyrrole-like nitrogen, and contained only traces of oxide nitrogen $(402 \sim 405 \mathrm{eV})$. Among the major advantages of the silk-derived activated carbon is that it showed a very high activity for the ORR; it also produced a high open-circuit potential when it was used as a cathode catalyst in a PEFC. Moreover, the activated carbon is heat-resistant; i.e. it showed a high catalytic activity for the ORR even after heat-treatment at $1200{ }^{\circ} \mathrm{C}$, although most nitrogen-containing carbon materials are prepared at temperatures below $1000{ }^{\circ} \mathrm{C}$. This may guarantee the durability of the carbon materials, because the greater the extent of graphitization of the carbon material, the greater should be its durability. Since large quantities of waste silk are produced the textile industry, silk-derived activated carbon is inexpensive.

Thus, the silk-derived activated carbon could, potentially, be used not only as a cathode catalyst itself, but could also serve as an "active support" that contributes directly to the ORR for a catalyst that guarantees a four-electron ORR.

\section{References}

1. Y. Shao, J. Sui, G. Yin and Y. Gao, Applied Catalysis B: Environmental, 79, 89 (2008).

2. J. Ozaki, N. Kimura, T. Anahara and A. Oya, Carbon, 45, 1847 (2007).

3. P. H. Matter, E. Wang, M. Arias, E. J. Biddinger and U. S. Ozkan, J. Mol. Catal. A: Chem., 246, 73 (2007).

4. R. A. Sidik, A. B. Anderson, N. P. Subramanian S. P. Kumaraguru and B. N. Popov, J. Phys. Chem. B, 110, 1787 (2006).

5. P. H. Matter, E. Wang, M. Arias, E. J. Biddinger and U. S. Ozkan, J. Phys. Chem. B, 110, 18374 (2006).

6. P. H. Matter and U. S. Ozkan, Catal. Lett., 109, 115 (2006).

7. R. Bashyan and P. Zelenay, Nature, 443, 63 (2006).

8. P. H. Matter, E. Wang and U. S. Ozkan, J. Catal., 243, 395 (2006).

9. P.H. Matter, L. Zhang and U.S. Ozkan, J. Catal., 239, 83 (2006).

10. J. Ozaki, S. Tanifuji, N. Kimura, A. Furuichi and A. Oya, Carbon, 44, 1324 (2006).

11. S. van Dommele, K. P. de Jong and J. H. Bitter, Chem. Commun., 4859 (2006).

12. S. Maldonado and K.L. Stevenson, J. Phys. Chem. B, 109, 4707 (2005).

13. S. Maldonado and K.J. Stevenson, J. Phys. Chem. B 109, 4707 (2005).

14. V. V. Strelko, N. T. Kartel, I. N. Dukhno, V. S. Kuts, R. B. Clarkson and B. M. Odintsov, Surf. Sci., 548, 281 (2004).

15. V. V. Strelko, V. S. Kuts and P. A. Thrower, Carbon, 38, 1499 (2000).

16. G. Chen, J. Guan, T. Xing and X. Zhou, J. Appl. Polym. Sci., 102. 424 (2006).

17. Y. J. Kim, Y. Abe, T. Yanagiura, K. C. Park, M. Shimizu, T. Iwazaki, S. 
Nakagawa, M. Endo and M. S. Dresselhaus, Carbon, 45. 2116 (2007).

18. K. Staczyk, R. Dziembaj, Z. Piwowarska and S. Witkowski, Carbon, 33, 1383 (1995).

19. J. R. Pels, F. Kapteijn, J. A. Moulijn, Q. Zhu and K. M. Thomas, Carbon, 33, 1641 (1995).

20. J. Casanovas, J. M. Ricart, J. Rubio, F. Illas and J. M. Jiménez-Mateos, J. Am. Chem. Soc., 118, 8071 (1996).

21. J.M.J. Mateos and J.L.G. Fierro, Surf. Interface Ana., 24, 223 (1996).

22. E. Raymundo-Piñero, D. Cazorla-Amorós, A. Linares-Solano, J. Find, U. Wild and R. Schlögl, Carbon, 40, 597 (2002).

\section{Figure captions}

Figure 1 Linear-sweep voltammograms for the ORR of the silk-derived activated carbons (a) CR700-AC, (b) CS900-AC, (c) CS1200-AC, (d) for activated carbon made from a phenolic resin, (e) for carbon black (Vulcan $\mathrm{XC}-72 \mathrm{R})$, and $(\mathrm{Pt})$ for a $\mathrm{Pt}(20 \%) / \mathrm{C}$ electrode, all measured in $0.5 \mathrm{M} \mathrm{H}_{2} \mathrm{SO}_{4}$ at $60{ }^{\circ} \mathrm{C}$ at $2000 \mathrm{rpm}$. The right-hand figure shows the voltammograms of the CS900-AC electrode for the ORR measured in oxygen-saturated $0.5 \mathrm{M} \mathrm{H}_{2} \mathrm{SO}_{4}$ at $60{ }^{\circ} \mathrm{C}$ by the rotating ring-disk electrode (RRDE) method at $2000 \mathrm{rpm}$. The ring current was revised with the collection efficienct of this measurement system.

Figure 2 The polarization curve, recorded at $27{ }^{\circ} \mathrm{C}$ by using a membrane-electrode assembly (MEA), for a PEFC comprising a $\mathrm{Pt}(20 \mathrm{wt} \%) / \mathrm{C}$ catalyst anode, a Nafion ${ }^{\circledR} 117$ membrane, and a cathode comprising CS1200-AC (loading $6.0 \mathrm{mg} \mathrm{cm}^{-2}$ geometric surface area) mixed with Nafion ${ }^{\circledR}$ ionomer. Pure hydrogen and pure oxygen were introduced at a pressure of $1 \mathrm{~atm}$ to the anode and cathode, respectively.

Figure 3 The X-ray diffraction patterns of the various carbon materials: (a) CS700-AC, (b) CS900-AC, (c) CS1200-AC, (d) activated carbon made from phenolic resin, and (e) carbon black (Vulcan XC-72R).

Figure 4 X-ray photoelectron spectra of the various carbon materials (a) CS700-AC, (b) CS900-AC, (c) CS1200-AC, (d) activated carbon made from phenolic resin, and (e) carbon black. The black lines are the raw spectra; the red, green, blue, and pink lines correspond to pyridine-like $\mathrm{N}$, pyrrole-like $\mathrm{N}$, quaternary $\mathrm{N}$, and oxide $\mathrm{N}$, respectively. 
Table 1 Atomic percent, atomic ratios and specific surface area of various carbon materials

\begin{tabular}{|c|c|c|c|c|c|c|c|}
\hline Carbon materials & C1s & N1s & O1s & $\left.\mathrm{N} / \mathrm{C}^{\mathrm{a}}\right)$ & $\mathrm{O} / \mathrm{C}^{\mathrm{a})}$ & $\left.\mathrm{N} / \mathrm{C}^{\mathrm{b}}\right)$ & $S_{\mathrm{BET}}{ }^{\mathrm{c})}\left(\mathrm{m}^{2} \mathrm{~g}^{-1}\right)$ \\
\hline CS700-AC & 83 & 5.0 & 12 & 0.061 & 0.15 & 0.046 & 1018 \\
\hline CS900-AC & 91 & 6.0 & 3.0 & 0.066 & 0.033 & 0.043 & 588 \\
\hline CS1200-AC & 97 & 0.67 & 2.3 & 0.007 & 0.023 & 0.008 & 464 \\
\hline $\begin{array}{l}\text { Activated carbon } \\
\text { (phenol resin-derived) }\end{array}$ & 94 & 0.00 & 6.5 & 0 & 0.070 & 0.000 & 1830 \\
\hline $\begin{array}{l}\text { Carbon black } \\
\text { (Vulcan XC-72R) }\end{array}$ & 97 & 0.00 & 3.0 & 0 & 0.031 & 0.001 & 217 \\
\hline
\end{tabular}

T. Iwazaki et al. Table 1
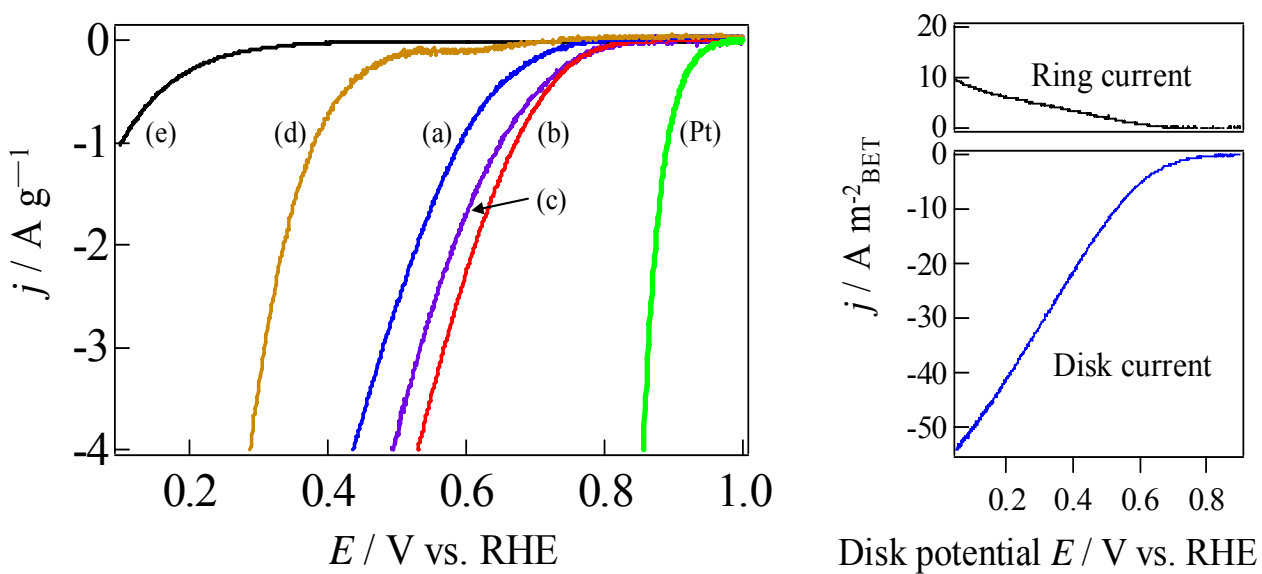

T. Iwazaki et al. Fig. 1 


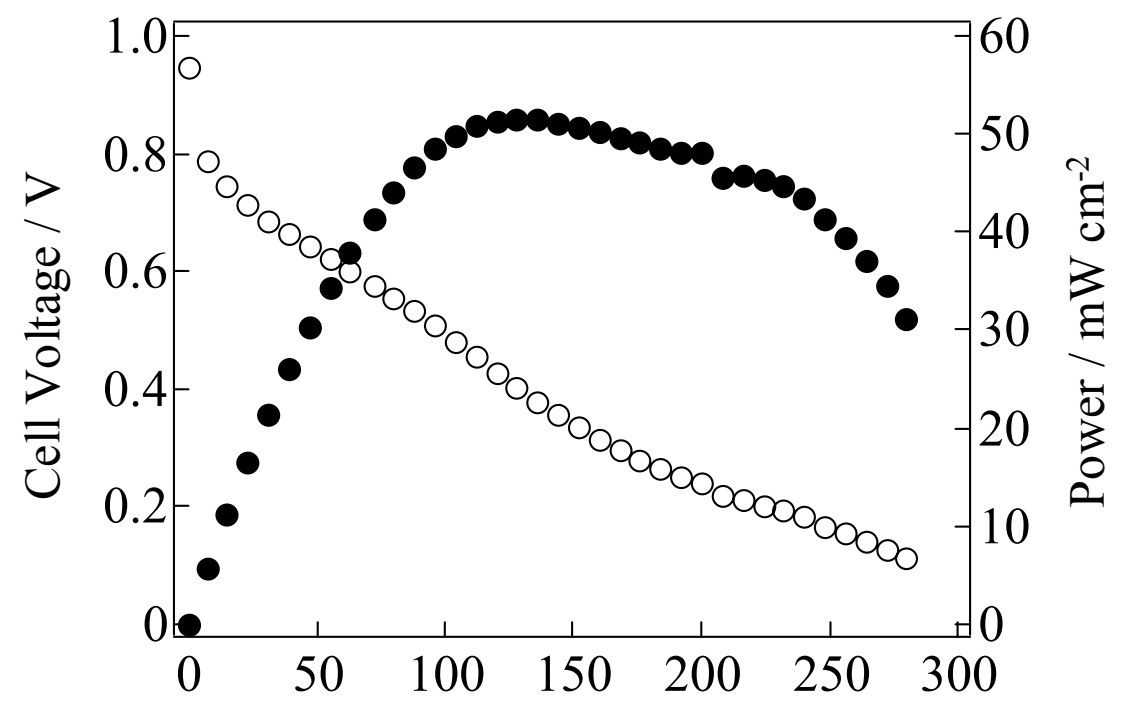

Current Density / $\mathrm{mA} \mathrm{cm}^{-2}$ (geometric)

T. Iwazaki et al. Fig. 2



T. Iwazaki et al. Fig. 3 


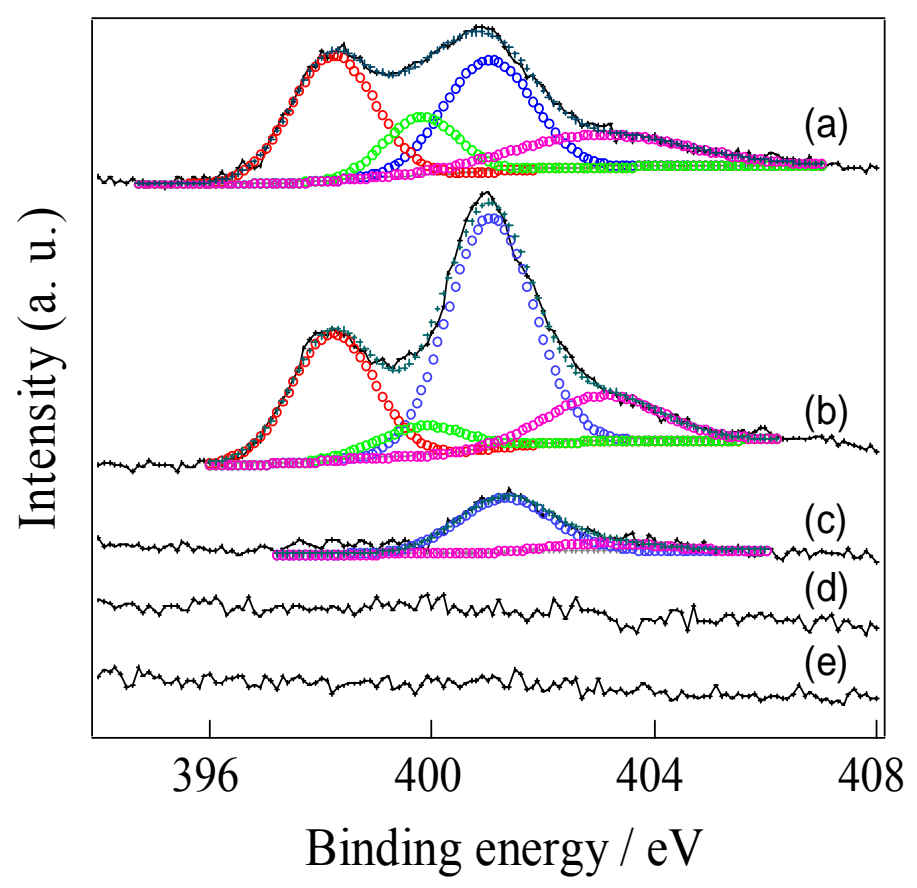

T. Iwazaki et al. Fig. 4 